\section{References}

Arfvedson, A. (1818) Undersoknigg af nagra vid Uto Jernmalmsbrott forekommande Fossilier, och af ett deri funnet eget Eldfast Alkali. Afhandlingar i Fysik, Kemi och Mineralogi, 6, 145-176.

BAASTRUP, P.C. (1964) The use of lithium in manic depressive psychosis. Comprehensive Psychiatry, 5, 396-408.

BaAstruP, P.C. \& SchOU, M. (1967) Lithium as a prophylactic agent. Its effect against recurrent depressions and manic-depressive psychosis Archives of General Psychiatry, 16, 162-172.

Blackwell, B. \& Shepherd, M. (1968) Prophylactic lithium: another therapeutic myth? Lancet, i, 968-971.

CADE, J.F.J. (1949) Lithium salts in the treatment of psychotic excitement. Medical Journal of Australia, 36, 349-352.

Corcoran, A.C., Taylor, R.D. \& Page, I. (1949) Lithium poisoning from the use of salt substitutes. Journal of the American Medical Association, 139, 685-688.

GLESINGER, B. (1954) Evaluation of lithium in treatment of psychotic excitement. Medical Journal of Australia, 41, 277-283.

Hanlon, L.W., Romaine, M., Gilroy, F.J. \& Dietrick, J.E. (1949) Lithium chloride as a substitute for sodium chloride in the diet. Journal of the American Medical Association, 139, 688-692.

HarTigan, G.P. (1963) The use of lithium salts in affective disorders. British Journal of Psychiatry, 109, 810-814.

Hawkins, J.B. \& DoRKen, P.R. (1969) Letter to the Editor. Lancet, i, 839-840.
Mayfield, D. \& Brown, R.G. (1966) The clinical laboratory and electroencephalographic effects of lithiumJournal of Psychiatric Research, 4, 207-219.

MoraCCI, E. (1931) Azione di alcuni sali applicati direttamente sui centri corticali sensitivo-motori del cane. Archivio di fisiologica, 29, 487-492, 493-511.

NoaCK, C.H. \& Trautner, E.M. (1951) The lithium treatment of maniacal psychosis. Medical Journal of Australia, 38, 219-222.

Radomski, J.L., Fuyat, H.N., Nelson, A.A. \& Smith, P.K. (1950) The toxic effects, excretion and distribution of lithium chloride. Journal of Pharmacology, 100, 429-444.

SARAN, B.M. (1969) Letter to the Editor. Lancet, i, 1208-1209.

Schou, M., Juel-Nielsen, N., Strömgren, E. \& Voldby, H. (1954) The treatment of manic psychosis by the administration of lithium salts. Journal of Neurology and Psychiatry, 17, 250-260.

Schou, M. (1968) Lithium in psychiatric therapy and prophylaxis. Journal of Psychiatric Research, 6, 67-95.

STERN, R.L. (1949) Severe lithium chloride poisoning with complete recovery. Journal of the American Medical Association, 139, 710-711.

Thomsen, K. \& Schou, M. (1968) Renal lithium excretion in man. American Journal of Physiology, 215, 823-827.

Trautner, E.H., Morris, R., Noack, C.H. \& Gershon, S. (1955) The excretion and retention of ingested lithium and its effect on the ionic balance of man. Medical Journal of Australia, 42, 280-291.

\title{
Pseudo-Meigs' syndrome associated with a pseudomucinous cystadenoma
}

\author{
K. C. LounG \\ M.B., B.Ch., M.R.C.O.G. \\ Lewisham Hospital, London, S.E.13
}

Meigs' Syndrome is the association of a benign ovarian tumour of fibrous tissue origin (fibroma, thecoma, granulosa-cell tumour and Brenner tumour) with hydrothorax and ascites, the latter disappearing on removal of the tumour.

The pseudo-Meigs' syndrome includes all other tumours of the ovary, benign or malignant, associated with hydrothorax and ascites, which latter also disappear on removal of the tumour, and is rarely encountered. The association of the condition with a pseudomucinous cystadenoma has been reported in eleven cases (Smith \& Boronow, 1967), and a further case is presented.

\section{Case report}

M.C. (Hospital No. B.45987), a married nullipara, aged 59 years, was referred to gynaecological outpatients after the routine discovery of an abdominal mass in a psychiatric unit.

There was a long history of recurrent attacks of depression which had been managed by electroconvulsive therapy. She complained of recent shortness of breath on exertion and stated that there had been some swelling of the abdomen for 2-3 months. The menopause had occurred at the age of 52 and there had been no post-menopausal bleeding. There was no other relevant medical history. Clinical examination showed no abnormality of the cardiovascular system. Examination of the chest revealed slight displacement of the trachea to the right with reduced air entry in the left chest, and dullness at the left base.

Abdominal examination showed the latter to be distended by a cystic swelling arising out of the pelvis, equivalent in height to a 26-week pregnancy. There was shifting dullness in both flanks. Pelvic examination showed no obvious abnormality and there was no nodularity in the Pouch of Douglas. The patient was admitted for investigation.

Investigations: $\mathrm{Hb}, 14.09 \%$, ESR normal, urine 
analysis normal, cervical smear negative, chest X-ray, the cardiac shadow was normal. A large left-sided pleural effusion was present.

\section{Further management}

Ascitic fluid was aspirated and sent for bacteriological and cytological examination. There was no evidence of tuberculous infection and cytological examination showed no tumour cells to be present. Pleural aspiration was carried out in order to obtain material for diagnostic purposes and to relieve the dyspnoea. The fluid was straw-coloured but examination showed no evidence of tuberculosis, and again no malignant cells were found.

In view of the negative findings, it was decided to proceed with exploratory laparotomy.

\section{Operation}

The abdomen was opened through a right paramedian incision. There was a large volume of ascitic fluid present and the left ovary was replaced by a large multilocular tumour, not adherent to the parietes. The right ovary appeared normal and there was no evidence of other intra-abdominal abnormality. The liver felt normal. After removal of the left ovarian cyst, the right ovary was removed, the uterus being left in situ in case intracavity radium was required at a later date. The abdomen was closed in layers.

The post-operative course was complicated by a low grade wound infection. Chest X-ray prior to the patient's discharge from hospital showed the fluid in the left chest to have been absorbed totally. In the two and a half years since operation the patient has remained well.

\section{Histological report}

The left ovarian tumour was multilocular and cystic, measuring $19 \times 17 \times 12 \mathrm{~cm}$. On gross section it had the typical appearance of a multilocular pseudomucinous cystadenoma, and this was confirmed on microscopic examination, there being no evidence in the sections examined of malignancy. The right ovary was histologically normal.

\section{Discussion}

In 1937, Meigs \& Cass reported seven patients with a fibroma of the ovary with ascites and hydrothorax, who were cured by removal of the fibroma. In 1951, Beecham, in a paper on the behaviour of pseudomucinous cystadenomata, described four cases with associated ascites and hydrothorax.

In 1954, Meigs, writing on pelvic tumours other than fibroma of the ovary associated with ascites and hydrothorax, commented that the lesion should be one made up mostly of fibrous tissue, so including thecomas, which are in the main fibrous, and also granulosa-cell tumours, for they are often fibrous and mixed with theca cells. Reviewing world literature, he found eight cases of pseudomucinous cystadenoma with ascites and hydrothorax. Smith \& Boronow (1967), reporting a further case of the syndrome, were able to find ten other cases in the literature.

Symptoms most frequently encountered were of dyspnoea and weight loss. The site of the pleural effusion was reported to be more common on the right side.

In the case reported here the symptoms were of abdominal swelling and dyspnoea. Cytological examination of pleural aspirate and peritoneal fluid showed an absence of malignant cells, although it was felt clinically that the combination of the two was most likely to be associated with malignant ovarian disease. The case further emphasizes the point that the presence of ascites and hydrothorax in the presence of an ovarian tumour must not preclude an innocent tumour.

\section{Acknowledgment}

I would like to thank Mr A. E. R. Buckle for permission to publish this case.

\section{References}

BeEcham, C.T. (1951) The behaviour of pseudomucinous cystadenomas. American Journal of Obstetrics and Gynecology, 1961, 755.

Meigs, J.V. \& CASs, J.W. (1937) Fibroma of the ovary with ascites and hydrothorax. American Journal of Obstetrics and Gynecology, 33, 249.

Meigs, J.C (1954) Pelvic tumours other than fibromas of the ovary, with ascites and hydrothorax. Obstetrics and Gynecology, 3, 471.

Smith, J.P. \& Boronow, R.C. (1967) Pseudo-Meig's syndrome with mucinous cystodenoma. Obstetrics and Gynecology, 30, 121. 